УДК.631.333.7

СВ.М. Ляшук, В.Ф.Дідух, д.т.н.

Луцький національний технічний університет

Т.П. Герасимик-Чернова, I.С. Бартошик

Любешівський технічний коледж Луцького національного технічного університету

\title{
ОСОБЛИВОСТІ ФОРМУВАННЯ ВРОЖАЮ КАРТОПЛІ
}

У статті запропоновано технологію формування умов живлення насіння картоплі з використання світового досвіду на основі твердих комплексних добрив(органічних $і$ мінеральних) за мінімальної норми їх внесення. Розглянуто конструктивнокомпонувальну схему комбінованого агрегату для садіння картоплі з встановленим пристроєм гравітаџійного типу для подачі картоплі.

КАРТОПЛЯ, ВРОЖАЙНІСТЬ, ВНЕСЕННЯ, МОДЕЛЬ, ОРГАНІЧНЕ ДОБРИВО

Постановка проблеми. Сьогодні, особливу увагу варто приділити картоплі яка, як сільськогосподарська культура, має значний потенціал і не реалізовується на світовому ринку через недотримання фітосанітарних норм через наявність цілого ряду хвороб, таких як рак, нематода та інші.

Дослідженнями доведено, що якісне використання природної родючості грунтів дозволяє збільшувати врожай сільськогосподарських культур на 20-50 відсотків. При цьому важливо забезпечити п'ять основних факторів, які у більшій мірі впливають на ріст та розвиток рослин: тепло, волога, використання районованих сортів, наявність елементів живлення та проведення заходів із захисту рослин від хвороб і шкідників [1].

Всі перелічені фактори є важливими i, у більшій мірі, залежать від вибору технології та технічних засобів садіння картоплі. Як показує досвід використання Голландської технології, продуктивність насіння картоплі залежить від умов розміщення його у сформованих зонах живлення. При цьому грунт має бути пухким, що забезпечує максимальний доступ до рослини тепла та вологи. Використання завищених норм внесення мінеральних добрив і значної кількістю хімічних засобів захисту рослин, призводить до втрат гумусу[2], розвитку бактерій та хвороб. Тому, вибір раціональної технології садіння картоплі та створення для 
цього технічних засобів, для отримання екологічної продукції, $\epsilon$ важливою науковою задачею.

Аналіз останніх досліджень і публікацій. Зростання кількості населення на Земній кулі вимагає збільшувати виробництво продуктів харчування, але наявні площі під сільськогосподарські культури фактично задіяні повністю. 3 року в рік в Україні вирощують картоплі в рази більше, ніж необхідно для внутрішнього споживання. Але, тим не менш, експорт залишається дуже незначним. За даними митної статистики у минулому році 3 України експортовано не більше 5 тис. тонн, а за 11 місяців поточного року - 14,7 тис. тонн картоплі[3]. Природній потенціал держави дозволяє змінити ситуацію за рахунок виробництва екологічно чистої продукції при раціональному застосуванні різних видів добрив: органічних і мінеральних.

В сучасних умовах господарювання необхідно повністю змінити концепцію застосування добрив, виходячи 3 отриманих наукових розробок. Одною із найважливіших складових цих розробок $є$ грунтова i рослинна діагностика у потребах рослин елементів живлення 3 врахуванням можливості забезпечення їх поживними речовинами. Це дає підставу для оптимізації визначення доз внесення добрив, забезпечення високих коефіцієнтів використання поживних речовин та їх окупність щодо приросту врожаю.

Як показує досвід, необгрунтоване збільшення норми внесення мінеральних добрив на природних родючих грунтах, призводить до втрати в них гумусу, поповнення якого можливе лише за рахунок внесення органічних добрив. Всі відомі органічні добрива, а також широка гама технічних засобів, передбачали їх поверхневе внесення [4]. Тому різке зменшення поголів'я в галуззі тваринництва та цілий ряд інших причин, вказують на необхідність використання локального способу внесення органічних добрив при вирощуванні сільськогосподарських культур.

Метою дослідження - $\epsilon$ вибір технології формування врожаю картоплі на стадії посадки насіння та напрямів вдосконалення технологічних процесів i технічних засобів, направлених на їх реалізацію.

Результати дослідження. Введення в систему вирощування сільськогосподарських культур науково обгрунтованої системи точного землеробства частково вирішує проблему зниження навантаження мінеральної частини у випадку використання поверхневого внесення добрив. Локальне внесення добрив у більшій мірі забезпечує рослини елементами живлення. 
При цьому локалізація дозволяє зменшувати норму внесення добрив у 1,5-2,0 рази із збереженням однакової прибавки врожаю порівнюючи з розкидним способом.

Локальне внесення твердих органічних добрив вимагає нових підходів до проектування технічних засобів які, у більшій мірі, $€$ комбінованими особливо для випадків одночасного використання органічних i мінеральних добрив. При цьому, необхідно врахувати також потребу у підживленні рослин, їх захисту від шкідників і хвороб. Але основні дози добрив, які формують зони живлення рослин, необхідно вносити на стадії посіву (посадки) сільськогосподарської культури.

Таким чином, загальна схема формування врожаю картоплі на стадії посадки може бути представлена відповідно до рис 1. Як видно зі схеми, технологія посадки картоплі залежатиме від виду добрив, за допомогою яких формуються зони живлення рослин і від технічних засобів іiі реалізації. Важливим елементом у даній технології $\epsilon$ підготовка грунту. Він має бути зрілим i добре розпушеним.

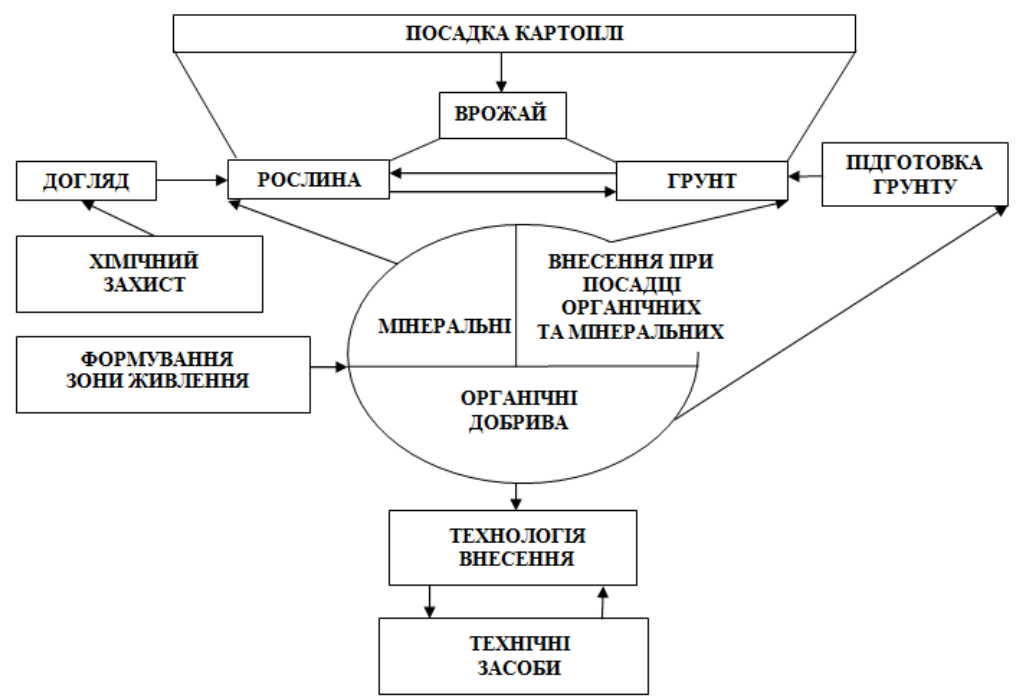

Рис. 1 - Модель формування врожаю картоплі на стадії посадки 
Зв'язок зон живлення напряму залежить від точності розрахункових значень мінеральних $\mathrm{i}$ органічних добрив, рівномірного їх змішування на етапі підготовки до вкладання на поверхню поля. Складність процесів локалізації внесення у грунт добрив пов'язане 3 необхідністю встановлення на агрегат додаткового обладнання для утворення зон живлення встановленої конфігурації та забезпечення точності розміщення насіння.

Сучасні нанотехнології, комп'ютеризація та автоматизація виробничих процесів, дозволили створити цілу серію комбінованих агрегатів для внесення різних видів добрив. До них слід віднести агрегати типу МВ3-4,5; Pronto; Maistro 11 RC; Creat Plains CTA 400/ADC 2220 та інші [6-7]. Такі технічні засоби передбачають локальне внесення добрив у грунт, але лише мінеральних добрив.

Забезпечення технічними засобами ведення органічного землеробства, вимагає створення нових або модернізацію існуючих машин. Такі комбіновані агрегати дозволить зменшити норму їх внесення не менше, ніж на 50 відсотків у порівнянні з розкидним способом.

При формуванні зон живлення рослин 3 використанням органічних добрив до них висуваються особливі вимоги (рис.2) щодо фізико-механічних властивостей. Добрива повинні бути сипкими з вологістю, що не перевищує 50 відсотків.

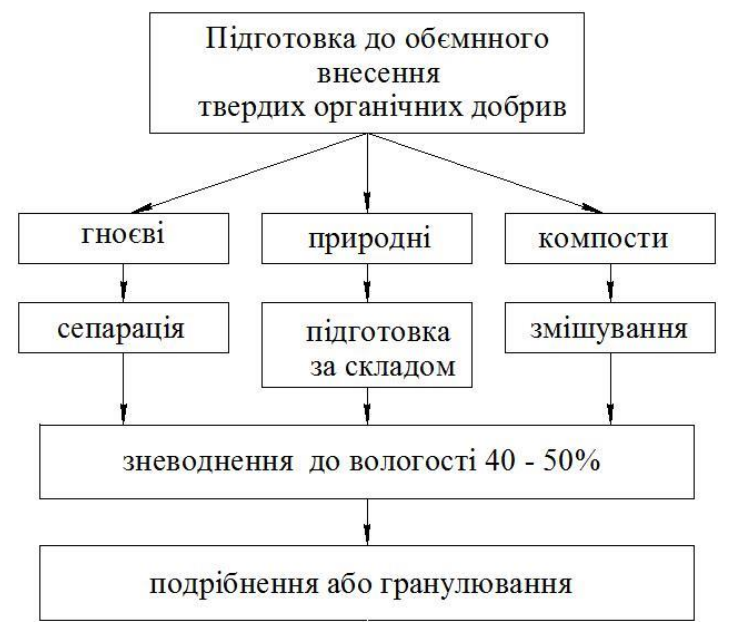

Рис. 2 - Вимоги до твердих органічних добрив для локального їх внесення 
Відсутність підстилкового гною, який $є$ складним для використання у свіжому вигляді, вказує на потребу створювати промислові підприємства 3 виробництва твердих органічних добрив. При цьому, наявність у природі широкої гами органічної сировини, вказує на те, що саме вони можуть стати основою для ведення органічного землеробства. Кожна територія характеризується місцевими сировинними ресурсами різного походження (гній ВРХ, послід, рослинні рештки, торф, сапропель, жом, дефекат, фосфорити, сапоніти тощо). Тому налагодження виробництва органо-мінеральних добрив має відбуватись 3 конкретною рецептурою для конкретних грунтових умов i сільгоспкультур.

Полісся - окрема грунтово-кліматична зона 3 площею 11768 тис. га, яка включає 4 млн. 42 тис. га орних земель[5]. Сьогодні продуктивність сільськогосподарських культур без застосування добрив у зоні Західного полісся $є$ досить низькою. Науковцями доведено, що найбільш раціональним способом реалізації біологічного потенціалу насіння картоплі на дерново підзолистих грунтах може стати локальне внесення комплексних добрив при одночасному формування зон живлення з органічних $\mathrm{i}$ мінеральних добрив.

Запропонований комбінований агрегат для посадки картоплі має бути оснований на реалізації способу бездефіцитного органо-мінерального живленні рослин за один прийом при посадці (рис.3).

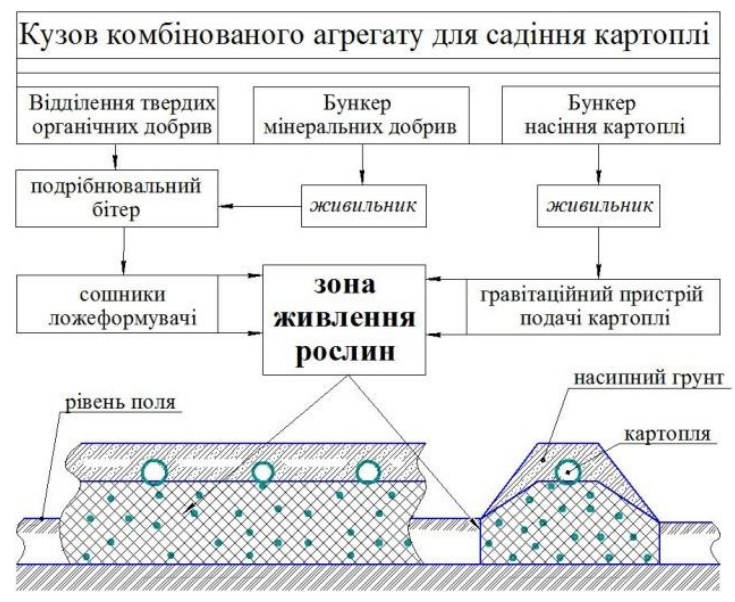

Рис. 3 - Схема комбінованого агрегату садіння картоплі та формування зон живлення рослин 
Аналіз запропонованої схеми вказує, що створення нового агрегату для садіння картоплі $\epsilon$ складним у проектуванні та виробництві. Тому, раціональним є підхід у модернізації відомих сільськогосподарських машин, через перетворення їх у комбіновані багатофункціональні агрегати. До таких слід віднести розкидачі твердих органічних добрив(рис.4).

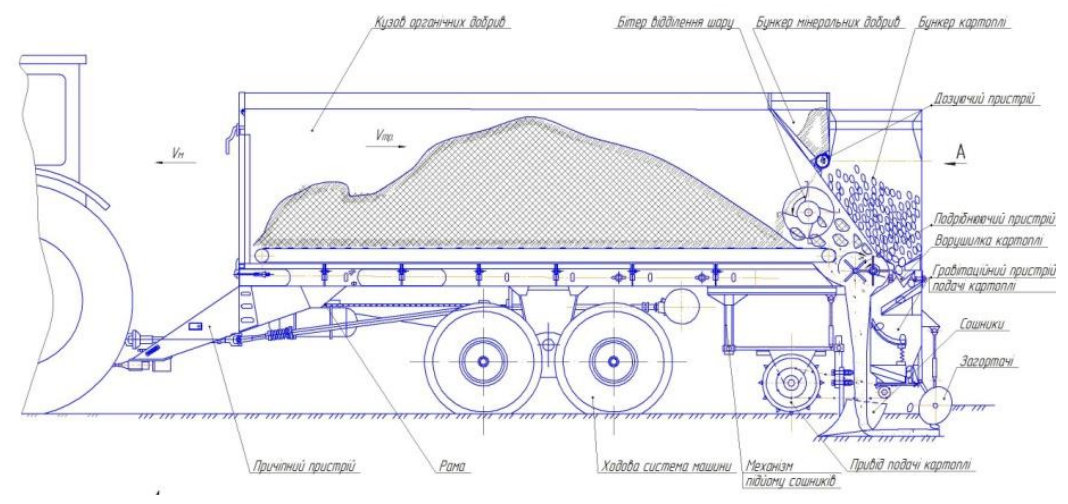

Рис. 4 - Схема комбінованого агрегату для садіння картоплі

Даний підхід до формування комбінованого агрегату базується на побудові агрегату з необхідних блоків. До таких слід віднести: базову машину, блок забезпечення внесення мінеральних добрив, блок картоплі та обладнання для змішування органічних і мінеральних добрив, їх подачу на поле для формування зон живлення, механізми, які забезпечують переведення окремих робочих органів з транспортного положення у робоче і навпаки.

Висновки. Запропонована методика переобладнання розкидача твердих органічних добрив у багатофункціональний агрегат для садіння картоплі з одночасним внесенням комплексних добрив та формування зон живлення рослин. Такий підхід забезпечить точність розміщення всіх складових, підвищити енергоефективність процесу вирощування сільськогосподарських культур.

\section{Література}

1. Запевалов М.В. Технологии и средства превентивных процессов по уходу за сельськохозяйсвенными культурами. FUNDAMENTAL RECSEARCH № 12, 2011. 326 - 331c. 
2. Ляшук В.М. Дослідження використання сапропелів при вирощуванні картоплі. / В.Ф Дідух, М.М. Поліщук, А.В. Хомич //Сільськогосподарські машини. Зб. наук. праць. Вип.40. - Луцьк, 2019. - c. 66-76.

3. https://ukranews.com/ua/interview/1844.

4. Бакум М.В. Сільськогосподарські машини. Ч.2. Машини для внесення добрив. У 2-х томах / М.В. Бакум, I.С. Ботрусь, А.Д. Михайлов, М.Г. Доценко, О.С. Войченко - Харків: ХНТУСГ, 2008. - T. 1. -285 c.

5. Застосування систем удобрення сільськогосподарських культур за використання комплексних добрив, що адаптовані до зональних грунтово-кліматичних умов Західного Полісся (науковопрактичні рекомендації) / В.А. Гаврилюк, О.В. Валецька, Т.П. Бортнік, А.М. Бортнік - Луцьк: ПП Іванюк В.П., 2019. - 33 с.

6. Дідух В.Ф. Дослідження технологій садіння картоплі. / В.В. Тарасюк, В.М. Ляшук, //Сільськогосподарські машини. Зб. наук. праць. Вип.36. - Луцьк, 2017. - с. 28-35.

7. http://www.horsch.com.

8. http://amacoint.com/AGRICULTURAL. 